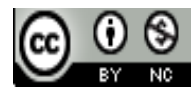

Jurnal Pendidikan Bahasa dan Sastra Indonesia is licensed under

A Creative Commons Attribution-Non Commercial 4.0 International License

\title{
Prosedur Pewarisan dan Penciptaan Sastra Lisan Tanduk Masyarakat Adat Genaharjo Kabupaten Tuban
}

\author{
Suantoko \\ Universitas PGRI Ronggolawe Tuban \\ E-mail: stsuantoko109@gmail.com
}

\begin{abstract}
Abstrak. Penelitian ini berusaha untuk memahami prosedur pewarisan dan proses penciptaan sastra lisan Tanduk masyarakat adat Genaharjo Kabupaten Tuban. Teori yang digunakan dalam penelitian yang dimaksud adalah teori struktur naratif ParryLord. Melalui teori tersebut, dapat dipahami bahwa prosedur pewarisan sastra lisan Tanduk tidak dilakukan dalam bentuk pendidikan formal seperti pewarisan penyair Yugoslavia. Pewarisan sastra lisan Tanduk dilakukan dengan cara ketiban sampur yaitu orang-orang yang dipilih berdasarkan seleksi alam sesuai dengan kehendak Sang Pencipta. Tukang Tanduk pemula hanya bertanya kepada tukang tanduk yang lebih senior. Pertanyaan paling inti yaitu tentang bermacam-macam Tanduk disesuaikan dengan tokoh yang dihormati dalam penampilan. Proses penciptaan sastra lisan Tanduk dilakukan secara spontan ketika tukang tanduk berhadapan langsung dengan tumpeng. Tukang tanduk tidak memiliki persiapan khusus dan tidak menghafal. Ia hanya mengingat-ingat formula kunci dalam penampilan sastra lisan Tanduk.
\end{abstract}

Kata Kunci: pewarisan; penciptaan; sastra lisan Tanduk; adat Genaharjo

\section{PENDAHULUAN}

Kajian sastra lisan, salah satu isu sentral adalah prosedur pewarisan dan prose penciptaan. Persoalan yang terkait dengan pewarisan umumnya membahas perihal bagaimana cara penampilan, makna, dan fungsi sastra tersebut diteruskan kepada orang lain dalam masyarakat kolektif. Setiap pewarisan kelisanan terdapat prosedur yang berbeda. Begitu juga dalam proses penciptaannya. Prosedur pewarisan dan penciptaan dalam kelisanan, terutama sastra lisan sangat menarik untuk kaji lebih mendalam. Baik dari sisi ahli waris atau pewaris sastra lisan tersebut.

Menurut Lord (2000:21-15), seorang calon guslar dalam menyampaikan proses pertunjukan harus menempuh tiga tahapan yaitu (1) tahapan pertama ketika calon seorang penutur memiliki keinginan untuk menjadi penutur. Hal ini akan dimulai ketika ia menyenangi cerita yang dituturkan seorang tukang cerita. semakin sering ia mendengar, maka cerita itu pun semakin akrab di telinganya. Pada tahapan ini, menyebutkan bahwa pengulangan frasa atau kata yang disebut dengan formula sudah masuk ke dalam ingatan penutur muda; (2) tahapan kedua dimulai ketika penutur muda tidak sengaja mendengar, namun sudah mulai belajar untuk menuturkan cerita yang sebelumnya sudah sering di dengar, baik tanpa atau dengan iringan instrument; dan (3) ketika tukang cerita muda mampu menampilkan sebuah cerita yang ia pernah dengar dari gurunya, di hadapan para penonton. Penutur muda akan menyelesaikan tahapan belajarnya dengan sering menampilkan dan mendengarkan tanggapan penonton, penutur muda ini kaan semakin mahir berimprovisasi, mengakumulasi, serta memperbaharui model formula yang dimiliki.

Dari ketiga tahapan belajar penutur cerita yang dikemukakan oleh Lord tersebut, formula terlihat menjadi salah satu aspek yang penting. Pada tahapan awal belajar, penampil puda sudah mulai mengenal formula dari cerita yang didengarnya. Sebagaimana Taum (2011), prosedur pewarisan teknik bercerita dari seorang penyair Yugoslavia (guslar) kepada muridnya dilaksanakan melalui semacam sistem pendidikan 'formal'. Masa berguru ini mencapai waktu rata-rata tiga tahun lamannya, yakni pencerita muda sampai mampu menyanyikan sebuah cerita secara utuh. Prosedur pewarisan selama belajar memanfaatkan formulaformula yang dinyanyikan oleh guru (guslar). Pencerita muda menemani gurunya mengadakan pertunjukan dengan menghafal formula.

Formula adalah istilah yang dikemukanan oleh Milman Parry dan Albert Lord setelah meneliti proses penciptaan karya seorang penyair Yunani yang bernama Homerus yang berjudul Illias dan Odyssea. Millman Parry dan Albert Lord melacak kembali dengan meneliti penyanyi cerita rakyat Yugoslavia.

Lord sebagaimana dikutip Amir (2013:120), mengemukakan bahwa saat penciptaan atau penggubahan, komposisi adalah hal yang penting karena setiap penceritaan menghasilkan ciptaan atau gubahan baru. Komposisi cerita digubah saat pertunjukan. Pencerita memiliki fungsi sebagai penggubah. Penampilan dilaksanakan secara cepat dengan tidak mempersapkan diri sebelumnya. Hal ini memerlukan kemahiran dan kebiasaan pencerita sehingga sebelum 
menjadi tukang cerita sebenarnya mereka memerlukan latihan.

Tukang cerita sudah memiliki ungkapan-ungkapan yang siap pakai dalam penggubahan sastra lisan. Ungkapanungkapan siap pakai atau tetap itu dapat digunakan setiap kali hendak menceritakan situasi yang sama. Keadaan ini disebut formula oleh Lord (2000:30).

Berdasarkan formula itu, seniman akan menggubah teksnya berdasarkan konvensi bentuk yang disebut ungkapan formulaik. Lord manambahkan bahwa penciptaan cerita lisan dalam pertunjukan yang diciptakan oleh tukang dendang senior dengan tukang dendang pemula memiliki nilai cita estetika formula yang tidak sama. Meskipun kata yang dikeluarkan sama dari mulut para pendendang. Tukang dendang senior lebih mahir dan lebih lincah dalam penggabungan formula, memiliki nilai rasa lebih tinggi di khalayak penikmat pertunjukan.

Sebagai produk budaya, sastra lisan tersebut memiliki karakteristik yang sama dengan sastra lisan yang berkembang di Indonesia pada umumnya. Sastra lisan yang berkembang di Genaharjo sebagai produk budaya masyarakat, memiliki nilai adi luhur. Nilai luhur yang terkandung dalam sastra lisan yang berkembang dalam masyarakat adat Genaharjo Kabupaten Tuban sangat dipegang teguh oleh masyarakat selaku pemilik budaya setempat.

Sastra lisan Tanduk perlu dilakukan penelitian karena beberapa alasan. Kesatu, sastra lisan Tanduk terus ada di tengah kehidupan masayarakat genaharjo. Kedua, sastra lisan Tanduk mampu mengikat tali persaudaraan antaranggota keluarga dan tetangga. Hal ini dapat dibuktikan, bahwa setelah terjadi peristiwa ritual budaya yang menampilkan sastra lisan Tanduk, masyarakat genaharjo masih ajeg melakukan tradisi ater-ater. Ketiga, sastra lisan Tanduk menyampaikan kebenaran yang diyakini oleh masyarakat Genaharjo sebagai produk budaya lisan (Suantoko, 2016:247).

Menurut apa yang dikemukakan Amir (2013:19), bahwa alasan pertama, sastra lisan ada dan terus hidup di tengah masyarakat sebagai produk budaya lisan. Kedua, dari sudut pandang folklor, sastra lisan dapat dilihat dari dua fungsi, (1) sastra lisan sebagai folklor berfungsi untuk membangun dan mengikat rasa persatuan kelompok; (2) sastra lisan menyimpan kearifan lokal. Ketiga, ada genre yang memperlihatkan hubungan antara kebudayaan dengan kebudayaan lain. Keempat, untuk beberapa kepentingan, sastra lisan dapat mewakili bangsa untuk bersanding dengan sastra lisan dari negara lain.

Penelitian sastra lisan berarti melakukan penyelamatan sastra lisan dari kepunahan. Penyelamatan dilakukan sebagai usaha dalam pewarisan nilai-nilai budaya, karena dalam sastra lisan ditemukan nilai moral, falsafah, ideologi, dan kearifan suatu bangsa. Nilai-nilai tersebut bisa diwariskan kepada anak cucu kelak. Dengan kata lain, penelitian ini dilakukan dalam upaya menyelamatkan sastra lisan Tanduk. Atas dasar uraian tersebut, sastra lisan Tanduk sangat menarik apabila dikaji dari aspek penciptaan dan prosedur pewarisan sastra lisan Tanduk masyarakat adat Genaharjo Kabupaten Tuban.

\section{METODE PENELITIAN}

Rancangan penelitian ini dirancang dalam bentuk penelitian kualitatif. Penelitian tersebut dibangun atas dasar data di lapangan. Data primer berupa teks Tanduk yang diperoleh dari penampilan sastra lisan Tanduk. Di samping itu, data primer diperoleh melalui wawancara para partisipan. Jenis data dalam penelitian ini adalah data kualitatif. Data yang dimaksud adalah data yang tidak bisa di ukur atau dinilai dengan angka secara langsung (Prastowo, 2010:3; Bungin, 2007:64; Ratna 2010:509). Data dalam penelitian kualitatif bukanlah berdasarkan atas tabel angkaangka hasil pengukuran atau penilaian secara langsung yang mana dianalisis secara statistik.

Penentuan informan menggunakan konsep Spradley (2007:61) dan konsep Danandjaja (1994:28), prinsipnya menghendaki, seorang informan itu paham terhadap budaya aslinya. Ada beberapa kriteria dalam penentuan informan menurut Spradley, yaitu (1) enkulturasi penuh, (2) keterlibatan lansung, (3) suasana budaya yang tidak dikenal,(4) cukup waktu, (5) non analitik. Kriteria yang lain yaitu pewaris aktif (active bearer) dan pewaris pasif (passive bearer). Selain konsep tersebut, penentuan informan didukung oleh konsep Endraswara (2006:57) dan Sudikan (2001:91), penentuan informan kunci harus orang yang bersangkutan memiliki pengetahuan luas mengenai permasalahan yang diteliti.

Pengumpulan data menggunakan beberapa teknik. Salah satunya mengacu pada metode etnografi Spradley (2007:63) The Development Research of Secuency, seperti; teknik participant observation dan indepth interview. Fontana dan Frey atau The Open Ended or Ethnographic Interview" (Adler dan Adler, dalam Endraswara, 2006:208). Kedua teknik tersebut merupakan teknik pengumpulan data melalui observasi alamiah dan wawancara mendalam. Kedua teknik ini berpegang teguh pada konsep Spradley (2007:106) bahwa peneliti berusaha menyimpan pembicaraan informan, membuat penjelasan berulang, menegaskan pembicaraan informan, dan tidak menanyakan makna tetapi gunanya. Di samping itu, menggunakan teknik dokumen, sebagaimana dikemukakan oleh Ratna (2010:234), bahwa teknik dokumen yang dimaksud adalah dokumen yang menunjuk pada masa lampau, dengan fungsi utama sebagai catatan atau bukti peristiwa, aktivitas, dann kejadian tertentu.

Analisis data dalam penelitian ini dilakukan melalui beberapa tahap.Tahapan dalam analisis data penelitian ini, tidak ada bedanya dengan tahapan dalam analisis data penelitian kualitatif. Menurut Sudikan (2014:136), tahapan tersebut meliputi: open coding, axial coding, dan selective coding untuk menghasilkan simpulan yang diangkat menjadi general design.

\section{HASIL DAN PEMBAHASAN}

\section{A. Prosedur Pewarisan}

Prosedur pewarisan sastra lisan Tanduk tidak dilakukan secara formal, seperti harus menempuh pendidikan profesi. Pewarisan sastra lisan Tanduk dilakukan dengan cara berdiskusi dalam kelompok kecil di rumah tukang tanduk. Tidak ada cara yang khusus dalam mewariskan sastra lisan Tanduk. Tukang tanduk hanya mengingat ingat formula yang dijadikan cara menampilkan dari awal, inti, dan 
penutup, tanpa melalui kursus. Meskipun sebenarnya tukang tanduk dituntut secara professional dalam penampilannya. Keprofesioalan itu ditempuh dengan cara mengingat-ingat sampai mahir dalam menampilkan. Tanpa harus menghafal, tukang tanduk harus dapat menghubungkan tumpeng yang dihadapinya dengan hajat yang dilaksanakan pemilik hajat.

Pewarisan sastra lisan Tanduk tidak begitu ketat dengan aturan tertentu. Hal ini tergantung kreativitas tukang tanduk untuk mengolah kemahirannya menggunakan bahasa. Formula yang dimiliki dapat dikembangkan sesuai kebutuhan. Sesuai dengan pendapat informan kunci, Sutadji berikut ini.

Pewarisan tersebut merupakan rahmat Tuhan, karena hanya orang pilihanlah yang mampu menjadi tukang tanduk (wawancara Sutadji, mantan Modin Genaharjo, pukul 19.00, tanggal 12 juni 2018).

Seorang tukang tanduk, menjadi pemimpin dalam kepungan tidak terbentuk melalui pemilihan atau yang lain yang ditentukan seperti pemilihan presiden. Menjadi tukang tanduk adalah amanah. Orang yang mangalami ketiban sampur, yang mampu meneruskan menjadi tukang tanduk. Orang-orang semacam ini adalah pilihan sang Pencipta jagat. Tidak semua orang atau anggota keluarga yang mampu menjadi pemimpin kepungan. Ketiban sampur adalah istilah yang dipakai masyarakat Genaharjo, bahwa tukang tanduk dipilih karena faktor alam. Hanya seleksi alamlah yang mampu menjadikan seseorang menjadi tukang tanduk. Dengan kalimat lain, menjadi tukang Tanduk tidak ada yang menyuruh, tidak ada yang melarang, dan tidak ada yang mempromosikan. Tukang tanduk muncul dalam suatu kolektif masyarakat apabila sudah tidak ada tukang tanduk lagi yang bisa dilirik.

Menurut Sumantri, salah satu tukang tanduk pemula, mengatakan bahwa dia menjadi tukang tanduk karena tukang tanduk yang lama pindah rumah. Dengan demikian di lingkungan kepungannya tidak ada satu pun tukang tanduk. Ia awalnya memberanikan diri ketika tidak ada tukang tanduk. Setelah bertahun-tahun mendengarkan dan mengamati tukang tanduk yang lama melalui formula yang diulang, ia mengingat-ingat formula tersebut. Awalnya, ketika pertama kali menghadapi tumpeng, mulutnya terkunci. Semua hafalannya hilang. Peristiwa semacam itu, kemudian ia tidak menghafal, hanya mengingat beberapa kata yang menjadi kunci dalam penampilan Tanduk yang bermacam-macam (wawancara Sumantri, tukang tanduk pemula di Genaharjo, pukul 19.30 WIB, tanggal 24 Juli 2018).

Prosedur pewarisan sastra lisan Tanduk tidak ditempuh dengan belajar formal atau berguru secara langsung, namun ditempuh dengan cara mengingat sejumlah formula kunci yang dijadikan pengingat. Formula-formula kunci tersebut dijadikan kunci dalam penciptaaan sastra lisan Tanduk ketika kepungan berlangsung.

Prosedur pewarisan sastra lisan Tanduk memiliki perbedaan dengan prosedur pewarisan dalam penampilan puisi lisan di Yugoslavia, sebagaimana dikemukakan oleh Lord (Taum, 2011:107), bahwa teknik pewarisan seorang penyair Yugoslavia kepada muridnya dilakukan dengan sistem pendidikan formal.
Teknik tersebut tidak berlaku dalam prosedur pewarisan Tanduk. Para tukang tanduk tidak mengikuti pendidikan secara formal. Mereka hanya mengingat formula-formula yang ditampilkan oleh tukang tanduk terdahulu. Tukang tanduk pemula lebih serius mendengarkan tukang tanduk yang sudah mahir untuk mengingat kata demi kata yang dirakit dalam satu baris. Tukang tanduk pemula, juga tidak meminta kepada tukang tanduk yang sudah mahir untuk mengajarinya, tetapi hanya menanyakan pakem keselamatan yang wajib dihormati dalam penampilan Tanduk.

Pewarisan Tanduk tidak terdapat guru atau murid. Status mereka sama dalam masyarakat sebagai orang yang ketiban sampur (kejatuhan selendang). Sebagai orang penerima sampur, harus siap untuk memimpin kepungan. Para tukang tanduk yang sudah mahir terkadang hanya bercerita kepada khalayak yang hadir pada saat kepungan, tanpa menunjuk satu di antara mereka yang hadir untuk dijadikan murid. Dengan demikian, prosedur pewarisan Tanduk berdasarkan seleksi alam. Seleksi alam yang dimaksudkan adalah seleksi alam berdasarkan kehendak Pencipta.

\section{B. Penciptaan}

Penciptaan sastra lisan pada umumnya dipermudah berkat adanya formula, ungkapan formulaik, dan tema siap pakai. Tukang cerita dapat merangkai formula-formula yang digunakan, begitu juga dengan sastra lisan Tanduk. Tukang tanduk pemula hanya menanyakan formula yang harus diingat. Tukang tanduk tidak harus menghafal tanduknya dari awal sampai akhir. Mereka cukup mengingat formula kunci secara benar. Formula yang diingat berasal dari nama tumpeng yang disajikan saat kepungan. Formula tersebut merupakan formula pakem yang harus ada pada setiap Tanduk yang sesuai dengan hajat yang dilaksanakan. Formula yang wajib diingat sebagaimana tabel di bawah ini.

TABEL 1

TUMPENG YANG WAJIB DIINGAT TUKANG TANDUK

\begin{tabular}{llll}
\hline No. & Tumpeng & \multicolumn{1}{c}{ Penghormatan } & Keterangan \\
\hline 1. & Sekul bucu & Sunan Kalijaga & \\
2. & Sekul buket & $\begin{array}{l}\text { Nabi Adam Ibu } \\
\text { Kawa }\end{array}$ & \\
3. & Sekul punar & $\begin{array}{l}\text { Mbok Dewi } \\
\text { Pertimah }\end{array}$ & \\
4. & Bubur abang & Nabi Ibrahim & \\
5. & Sekul liwet & Nabi Syis & \\
6. & Bubur lemu & Nabi bodo & \\
7. & Kupat lepet & Nabi Nuh & \\
8. & Jajan Pasar & Dampo Awang & \\
9. & Sekul gurih & 1. Nabi Panutan & Mangku Griya \\
& & 2. Nabi Rasul & Mangku Griya \\
& & 3. Nabi & kirim Donga \\
& & Muhammad & \\
& & 4. Nabi Mustaka & Keleman \\
& & 5. Nabi Mustapa & Ngrujaki/Brokohi \\
10. & Pala & Imam Tabut Nabi & \\
& pendhem & Daud & \\
11. & Pulo Gula & Dadung Awuk & \\
& Ampo & & \\
\hline
\end{tabular}

Tabel tersebut, dapat membantu dalam penampilan sastra lisan Tanduk. Tukang Tanduk tidak perlu mengingat secara 
detil. Mereka hanya mengingat formula tersebut kemudian dikembangkan lmelalui sarana retorika berbahasa. Formula di atas ditambah dengan penghormatan kepada Bapa Biyang. Formula penghormatan semacam ini tidak boleh ditinggalkan dalam penciptaan Tanduk. Apabila lupa menampilkan penghormatan tersebut, biasanya tukang Tanduk mengulang kembali Tanduk yang ditampilkan. Penciptaan atau penggubahan Tanduk dilakukan ketika tukang tanduk sudah menghadapi tumpeng. Dengan demikian, tukang Tanduk tidak dapat mereka-reka atau menghafal dari rumah. Penciptaan Tanduk adalah sekali jadi (sabda dadi) di depan tumpeng.

Penciptaan sastra lisan sebagai suatu kesenian dan karya estetika yang disampaikan kepada khalayak pendukung sastra tersebut perlu diperhatikan. Aspek-aspek penyampaian sastra lisan yang dibicarakan Lord, sebagaimana dikutip Amir (2013:115), ditemukan beberapa istilah, yaitu composer (penggubah), creator (pencipta), dan performer (penampil). Penggubah adalah orang yang merangkai ungkapan-ungkapan tertentu bagi penyuguhan, dan pertunjukan sastra lisan dengan menggunakan formula yang dipadukan dengan komposisi alat musik. Pencipta adalah orang yang memiliki gagasan kreatif untuk memunculkan sesuatu. Sedangkan penampil adalah orang yang menampilkan puisi lisan pada saat pertunjukan.

Berdasarkan pendapat tersebut, proses penciptaan sastra lisan tidak mengikuti aspek semacam itu. Proses penciptaan Tanduk tidak serumit itu, harus ada pencipta, penggubah, dan penampil. Penampil, penggubah, dan pencipta menjadi satu dan dinamakan tukang tanduk. Seorang tukang tanduk merangkap ketiganya. Tukang tanduk memiliki kekhasan. Ia tidak mempertimbangkan khalayak atau orang yang hadir menyaksikan penampilannya, seperti pada pertunjukan sastra lisan pada umumnya. Hal ini dikarenakan penampilan Tanduk lebih mementingkan kesakralan dalam penampilnnya dan meninggalkan sisi pertunjukan yang menggunakan alat musik.

Penciptaan Tanduk menjadi satu dalam penampilan. Tukang Tanduk mencipta sekaligus menampilkan dengan mengingat formula berdasarkan tumpeng yang dihadapinya. Formula-formula tersebut dikembangkan berdasarkan kemahiran tukang Tanduk dalam memanfaatkan sarana puitika dan retorika berbahasa. Kunci penciptaan Tanduk secara spontanitas tergantung pada tumpeng yang dihadapi tukang tanduk. Dengan demikian, estetika sebuah penampilan Tanduk lebih bermakna bagi pemilik hajat dan para saksi yang hadir.

Proses penciptaan Tanduk tidak terlepas dari variasi penampilan baik pada awal dan akhir Tanduk, sebagaimana contoh berikut ini.

TABEL 2

VERSI PEMBUKA SASTRA LISAN TANDUK

\begin{tabular}{ll}
\hline \multicolumn{1}{c}{ TEKS } & \multicolumn{1}{c}{ Versi 1 } \\
\hline Nuwun para bapak lan sederek & Mohon para bapak dan saudara \\
ingkang sampun nglempak & yang sudah berkumpul di sini \\
dhateng mriki sedaya. & semua \\
Kula sadremi ngikraraken & Saya mewakili mengikrarkan \\
kajatipun Sakim & hajat sakim \\
\hline
\end{tabular}

Ingkang gadah kajat

Nanging sampun rembug

rukun sakeluarganipun sedaya

Ageng alit, jaler estri, sepuh

nem, ingkang dados satunggal

kaniatanipun

\begin{tabular}{rr}
\hline & Versi \\
\hline TEKS
\end{tabular}

Nuwun para bapak, tokoh

masyarakat, sesepuh, lan sederek

Ingkang sampun nglempak

dhateng mriki sedaya.

Kula sadremi ngikraraken

kajatipun Rasto ingkang gadah

kajat

Nanging sampun rembug

rukun sakeluarganipun sedaya

Ageng alit, jaler estri, sepuh

nem, ingkang dados satunggal

kaniatanipun

\begin{tabular}{ll}
\hline Versi 3 & \\
\hline TEKS & TERJEMAHAN \\
\hline Nuwun para bapak, Sesepuh, & Mohon para Bapak, Sesepuh, \\
Alim, Ulama, lan Sederek & Alim, Ulama, dan Saudara \\
Ingkang sampun nglempak & Yang sudah berkumpul di \\
dhateng mriki sedaya & tempat ini semua \\
Ing wekdal punika, kula & Di waktu ini, saya hanya \\
sadremi ngikraraken kajatipun & mengikrarkan hajat Podho \\
Podho & Yang memiliki hajat \\
Ingkang gadah kajat & Beliau sudah mermusyawarah \\
Panjenenganipun sampun & sekeluarganya semua \\
rembug rukun sakeluarganipun & Besar kecil, laki-laki \\
sedaya & perempuan, tua muda, yang \\
Ageng alit, jaler estri, sepuh & menjadi satu niat \\
nem, ingkang dados satunggal & \\
kaniatan & \\
& \\
\hline Versi 4 & \\
\hline TEKS & TERJEMAHAN \\
\hline Nuwun para Bapak lan & Mohon para Bapak dan saudara \\
Ingkang sinareh sampun cekap & serta sesepuh \\
tata linggihane & Yang mantap menata tempat \\
Kula aturi biyantu pandonga & Saya berharap membantu doa \\
piyambak-piyambak. & masing-masing \\
Kula sakdremi masrahaken & Saya hanya mengikrarkan \\
hajatipun Kandar ingkang & hajatnya Kandar yang \\
gadhah hajat & memiliki hajat \\
Ning piyambake sampun & Beliau sudah bermusyawarah \\
rembug rukun sakeluarganipun & sekeluarganya \\
&
\end{tabular}

Yang memiliki hajat

Namun sudah bermusyawarah

seluruh keluarganya semua

Besar kecil, laki-laki

perempuan, tua muda sudah

menjadi satu niat

\section{Mohon para bapak, tokoh \\ masyarakat, sesepuh, dan saudara \\ Sudah berkumpul di sini semua Saya hanya mengikrarkan hajat Rasto yang memiliki hajat \\ Namun sudah bermusyawarah sekuluarganya semua Besar kecil, laki-laki perempuan, tua muda, yang sudah menjadi satu niatnya}

TABEL 3

VERSI PENUTUP SASTRA LISAN TANDUK

\begin{tabular}{ll}
\hline \multicolumn{1}{c}{ Tersi 1 } \\
\hline \multicolumn{1}{c}{ TEKS } & \multicolumn{1}{c}{ TERJEMAHAN } \\
\hline Sabakdanipun anggen kula & Telah selesai saya mengikrarkan \\
atur masrahaken & Tuhan semesta alam \\
Gusti Allah kang ngijabahi & mengabulkan \\
Kasesenan Derek kang & Kesaksian Saudara yang duduk \\
lenggah mriki sedaya & di sini semua \\
Inggih sampun & Iya sudah \\
\hline \multicolumn{1}{c}{ TEKS } & Versi 2 \\
\hline
\end{tabular}


Sabakdane anggenipun kula ngikraraken

Kasesenan Derek kang

lenggah mriki sedaya
Telah selesai saya mengikrarkan Kesaksian Saudara yang duduk di sini semua

\begin{tabular}{|c|c|}
\hline \multicolumn{2}{|c|}{ Versi 3} \\
\hline TEKS & TERJEMAHAN \\
\hline $\begin{array}{l}\text { Mugiya ajeng rahajeng } \\
\text { rahayu wilujeng }\end{array}$ & $\begin{array}{l}\text { Semoga diberikan ketentraman } \\
\text { dan kebahagiaan }\end{array}$ \\
\hline Anggenipun nampi & Dia menerima ketentraman dari \\
\hline $\begin{array}{l}\text { kawilujengan saking Gusti } \\
\text { Allah }\end{array}$ & Allah \\
\hline Sabakdane anggen kula & Telah selesai saya mengikrarkan \\
\hline masrahaken & Kesaksian Saudara semua saya \\
\hline $\begin{array}{l}\text { Kesesenan Derek sedaya kula } \\
\text { aturi maos Al-Fatihah }\end{array}$ & harapkan memcaca al Fatihah \\
\hline \multicolumn{2}{|c|}{ Versi 4} \\
\hline TEKS & TERJEMAHAN \\
\hline $\begin{array}{l}\text { Sabakdane anggenipun kula } \\
\text { ngikraraken }\end{array}$ & $\begin{array}{l}\text { Telah selesai saya mengikrarkan } \\
\text { Kesaksian Saudara yang duduk }\end{array}$ \\
\hline $\begin{array}{l}\text { Kasesenan Derek kang } \\
\text { lenggah mriki sedaya } \\
\text { Sumangga. Al-Fatihah }\end{array}$ & $\begin{array}{l}\text { di sini semua } \\
\text { Silakan. Al Fatihah }\end{array}$ \\
\hline
\end{tabular}

Dalam pembuka dan penutup Tanduk tersebut, terdapat variasi ketika membuka dan menutup penampilan Tanduk. Penampilan sastra lisan Tanduk sulit untuk menemukan kesamaan yang mutlak. Penampilan tersebut pasti terdapat variasi-variasi sesuai kemampuan dan kemahiran berbahasa tukang Tanduk. Tanduk pembuka versi 1, 2, dan 4 terdapat lima baris. Awal baris memiliki kesamaan dengan pengulangan kata nuwun. Perbedaan variasi terletak pada khalayak yang disapa. Versi 4 menunjukkan variasi bahwa khalayak yang disapa sudah mantap dengan tempat duduknya terdapat pada larik yang berbunyi ingkang sinareh sampun cekap tata linggihane.

Penutup Tanduk terdapat variasi untuk mengakhiri sebuah penampilan Tanduk. Variasi 1, 2, 3, dan 4 terdapat perbedaan formula yaitu masrahaken dan ngikraraken. Kedua kata tersebut berbeda tetapi memiliki makna yang sama yaitu mengakhiri Tanduk. Variasi lain yang berbeda adalah saran untuk membaca surat Al Fatihah. Tidak semua penutup Tanduk diakhiri dengan saran untuk membaca surat tersebut.

\section{SIMPULAN}

Berdasarkan hasil analisis data yang telah dilakukan dalam penelitian ini dapat disimpulkan sebagai berikut.

a) Prosedur pewarisan sastra lisan Tanduk tidak dilakukan dalam bentuk pendidikan formal seperti pewarisan penyair Yugoslavia. Pewarisan sastra lisan Tanduk dilakukan dengan cara ketiban sampur yaitu orang-orang yang dipilih berdasarkan seleksi alam sesuai dengan kehendak Sang Pencipta. Biasanya tukang tanduk pemula hanya bertanya inti dari bermacam-macam Tanduk disesuaikan dengan tokoh yang dihormati dalam penampilan.

b) Proses penciptaan sastra lisan Tanduk dilakukan secara spontan ketika tukang tanduk berhadapan langsung dengan tumpeng. Tukang Tanduk tidak memiliki persiapan khusus dan tidak menghafal. Ia hanya mengingat-ingat formula kunci dalam penampilan sastra lisan tanduk.

Penelitian ini sangat bermanfaat untuk pengembangan konsep sastra lisan yang berkembang di Indonesia terutama pulau Jawa. Pengembangan semacam ini diharapkan mampu memberikan kontribusi baik secara teoritis mengenai teori sastra lisan maupun empiris berdasarkan penemuan data di lapangan. Baik pemanfaatan dalam cara menciptakan dan prosedur mewariskan kelisanan ke generasi selanjutnya. Berdasarkan hal-hal tersebut, rekomendasi yang mendesak yang perlu dilakukan peneliti berikutnya adalah penelitian sastra lisan Tanduk dikaitkan dengan wacana kultural. Bagaimanapun juga, sastra lisan Tanduk adalah salah satu produk wacana lisan yang berkembang di masyarakat Genaharjo.

\section{DAFTAR PUSTAKA}

Amir, Adriyetti. (2013). Sastra Lisan Indonesia. Yogyakarta: Penerbit Andi.

Bungin, Burhan. (2007). Penelitian Kualitatif. Jakarta:Kencana

Danandjaja, James. (1994). Folklor Indonesia: Ilmu Gosip, Dongeng, dan Lain-lain. Jakarta: Pustaka Utama Grafiti.

Endraswara, Suwardi. (2006). Metodologi Penelitian Kebudayaan. Yogyakarta: Gadjah Mada University Press.

Lord, Albert B. (2000). The Singer of Tales. London: Harvard University Press.

Prastowo, Andi. (2010). Menguasai Teknik-teknik Koleksi Data Penelitian Kualitatif. Yogyakarta: Diva Press.

Ratna, Nyoman Kutha. (2010). Metodologi Penelitian Kajian Budaya dan Ilmu Sosial Humaniora pada Umumnya. Yogyakarta: Pustaka Pelajar.

Spradley, James P. (2007). Metode Etnografi. (diterjemahkan oleh Misbah Zulfa Elizabeth) .Yogyakarta: Tiara Wacana.

Suantoko, S. Fungsi Sastra Lisan "Tanduk" Masyarakat Genaharjo Kabupaten Tuban Bagi Masyarakat Pendukungnya. Jurnal Pendidikan Bahasa dan Sastra UPI, 16(2), 246-256.

Sudikan, Setya Yuwana. (2001). Metode Penelitian Kebudayaan. Surabaya: Citra Wacana.

Sudikan, Setya Yuwana. (2014). Metode Penelitian Sastra Lisan. Lamongan: Pustaka Ilalang Group.

Taum, Yoseph Yapi. (2011). Studi Sastra Lisan: Sejarah, Teori, Metode, dan Pendekatan Disertai Contoh Penerapannya.Yogyakarta: Lamalera. 